\title{
乱流モデルによる二次元表層密度噴流の鉛直混合現象の数值計算 \\ CALCULATION OF VERTICAL MIXING IN TWO-DIMENSIONAL TURBULENT BUOYANT SURFACE JET WITH TURBULENCE MODELS
}

\author{
室田 明*.中辻啓二**.藤崎豊*** \\ By Akira MUROTA, Keiji NAKATSUJI and Yutaka FUJISAKI
}

\begin{abstract}
Applicability of turbulence models to a two-dimensional buoyant surface jet is examined through comparison with experimental data. A $k^{-} \epsilon$ turbulence model is found to overpredict the turbulent transport of the stresses so as to promote the vertical spreading of buoyant surface jet, because it cannot represent the anisotropy of turbulence. For taking account of the damping effects of the gravitational field and the free surface on the turbulence structure accurately, an algebraic Reynolds stress model (ASM) is examined with corrections to the pressure interaction terms at the free surface. The ASM tested produces a good agreement with measurements on the flow development and turbulence characteristics of buoyant surface jet. The predicted results also show the dependence of turbulence structure on gradient Richardson numbers.

Keywords : turbulence model, numerical calculation, buoyant surface jet, stable stratification, free surface
\end{abstract}

\section{1. 緒言}

本研究は, 近年機械工学や原子力工学等数多くの分野 において利用されている乱流モデルを二次元表層密度噴 流の流動解析に適用したものである.

表層密度噴流は密度の異なる流体を水表面に放出した ときに観察される流動であり, 自由な乱れのせん断流効 果と浮力による成層安定効果とが共存する流れ場であ る. しかも，その上下を水表面之密度境界面の 2 つの自 由境界に挟まれている点に特徴がある. また, それは密 度流的に射流から常流へと遷移する流れ場でもある. し たがって, 開水路流れにみられる跳水現象之同様に, 表 層密度噴流は下流側の条件によって内部跳水を生起し, さらに成層流へと流動形態を変化させることもある（室 田・ 中辻・ 中村1 参照).

それゆえ, 乱流の数值計算でもつぱら利用されている Patankar-Spalding ${ }^{2)}$ の開発した parabolic-type の数値 計算コードは適用できない. また, 自由水表面の取扱い, 乱流の表現, 特に乱れに及ぼす浮力効果や自由水表面の

* 正会員 工博 大阪大学教授 工学部土木工学科 （开565 吹田市山田丘 2-1)

** 正会員 工博 大阪大学助教授 工学部土木工学科(同上)

*** 学生会員 元 $\cdot$ 大阪大学大学院前期課程学生 (同上)
影響の表現, 等々, 数值計算を実行するに際して数多く の問題点がある.

今まで数多くの高次乱流モデルが提案されてきた。検 証実験等を通じてそれらが種々のせん断流場において妥 当であるという証明もなされてきた. 係数の值もある程 度固定化されつつある. 土木の分野の乱流計算で残され た課題は乱流特性に及ぼす自由水表面と浮力の影響の評 価であると考えられる.

Gibson-Launder ${ }^{3)}$ が代数的応力モデルを二次元表層 密度噴流に適用して以来, McGuirk-Rodi ${ }^{4}$, RaithbySchneider $^{5)}$, Leschziner ${ }^{6)}{ }^{\text {P McGuirk-Papadimitriou }}{ }^{7)}$ 等が三次元あるいは二次元表層密度噴流や内部跳水へ 種々の高次乱流モデルの適用を試みている. しかしなが ら, 濃度あるいは温度変動場での乱流計測が困難である ため, 信頼に足る実験データが乏しく, 予測結果の検証 は実験値との定性的比較にとよ゙まっているのが実状であ る. 乱流モデルの高度化に伴い, 実験值の精度の向上が 要求されるのは必然の結果である.わが国においても二, 三の適用例 ${ }^{81.99}$ があるが, 比較対象とする実験の信頼性 に問題があり, 結論を得るまでには至っていない.

本研究では, 先に発表した二次元表層密度噴流の数值 計算プログラム ${ }^{10)}$ を基本に， $k^{-} \epsilon$ 二方程式モデルと代数 的応力モデル (ASM) の適用を試みる. 著者らが長年 
にわたって実施してきた乱流計測結果 ${ }^{11)}$ と比較すること により，乱流モデルの有効性を検討する.

\section{2. 二次元表層密度噴流の基礎方程式}

\section{（1）平均流動場}

非圧縮性流体, ブーシネスク近似, 静水圧近似および 境界層近似の諸仮定を適用すれば，流速および密度変化 をもたらす保存物質（たとえば, 塩分濃度, 熱) を支配 する方程式は次のように表現される.

$$
\begin{aligned}
& \frac{\partial U}{\partial x}+\frac{\partial W}{\partial z}=0 \\
& \frac{\partial U}{\partial t}+U \frac{\partial U}{\partial x}+W \frac{\partial U}{\partial z}=-\frac{1}{\rho_{a}} \frac{\partial P}{\partial x}+\frac{\partial}{\partial z}(-\overline{u w}) \\
& 0=g-\frac{1}{\rho} \frac{\partial P}{\partial z} \\
& \frac{\partial B}{\partial t}+U \frac{\partial B}{\partial x}+W \frac{\partial B}{\partial z}=\frac{\partial}{\partial z}(-\overline{w b})
\end{aligned}
$$

ここに,座標系は静水時の放流口の水表面を原点に選び, 流下方向に $x$ 軸，鉛直下向きに $z$ 軸をとる. $U, W$ は それに対応する平均流速成分， $u, w$ は乱れ変動成分で ある. 密度 $\rho$ は保存物質の濃度に比例する之仮定する. 浮力パラメーター $B$ は周囲環境水の密度 $\rho_{a}$ を用いて次 式で表わされる. $b$ は平均浮力 $B$ からの変動成分であ る.

$$
B=g \frac{\rho_{a}-\rho}{\rho_{a}} \geqq 0
$$

水深 $z$ における平均圧力 $P$ は式（3）を水表面（ $z=$ 一ろ）から $z$ まで積分して,

$$
P=\int_{-5}^{z} \rho g d z=\int_{0}^{z} \rho_{a} g d z+\rho_{a} g \zeta-\rho_{a} \int_{-5}^{z} B d z \cdots
$$

となる. したがって, 圧力勾配 $\partial P / \partial x$ は水表面勾配 $d \zeta / d x$ と浮力勾配 $\partial B / \partial x$ の関数として表現される.

\section{（2）乱流変動場}

基礎方程式（1)（４）を完結させるためには，レイ ノルズ応力 $-\overline{u w}$ 之乱流浮力流束 $-\overline{w b}$ を特定する必要 がある.この乱流輸送の完結問題が乱流研究の最大の難 問であり, 最近の研究ではその解決手法としてさまざま な乱流モデルが提唱されている。

本論文で適用するモデルは次の 2 つである. 1 つは勾 配拡散型モデルであり, 渦動粘性係数 $\nu_{t}$ は $k-\epsilon$ 二方程 式モデルから算出される.このモデルは現在数多くのせ ん断乱流場に適用され，成果をあげている，いま1つは $-\overline{u_{i} u_{j}}$ と- $\overline{u_{i} b}$ の輸送方程式を直接解くレイノルズ応 力モデルを簡略化した代数的応力モデルである. 基礎方 程式および定数は以下に示すとおりである.

a) $k-\epsilon$ 二方程式モデル

レイノルズ応力および乱流浮力流束は次式のように渦
動粘性係数 $\nu_{t}$ 之渦拡散係数 $\Gamma_{t}$ に関連づけてモデル化さ れる.

$$
\begin{aligned}
& -\overline{u w}=\nu_{t} \frac{\partial U}{\partial z}, \quad-\overline{w b}=\Gamma_{t} \frac{\partial B}{\partial z} \\
& \nu_{t} \equiv c_{\mu} \frac{k^{2}}{\epsilon}
\end{aligned}
$$

渦拡散係数は乱流 Schmidt 数 $\sigma_{t}\left(=\nu_{t} / \Gamma_{t}\right)$ を介して渦 動粘性係数と関連づけられる. 上式は, 乱流の特性が乱 れエネルギー $k\left(=1 / 2 \overline{u_{i}^{2}}\right)$ と粘性消散率 $\epsilon(=\nu$. $\left.\overline{\partial u_{j} / \partial x_{i} \cdot \partial u_{i} / \partial x_{j}}\right)$ の 2 つ特性量で決定されること を意味している. $k$ および $\epsilon$ の分布は次の半経験的輸送 方程式から算出できる.

$$
\begin{aligned}
& \frac{\partial k}{\partial t}+U \frac{\partial k}{\partial x}+W \frac{\partial k}{\partial z}=\frac{\partial}{\partial z}\left(\frac{\nu_{t}}{\sigma_{k}} \frac{\partial k}{\partial z}\right)+\nu_{t}\left(\frac{\partial U}{\partial z}\right)^{2} \\
& +\frac{\nu_{t}}{\sigma_{t}} \frac{\partial B}{\partial z}-\epsilon \\
& \frac{\partial \epsilon}{\partial t}+U \frac{\partial \epsilon}{\partial x}+W \frac{\partial \epsilon}{\partial z}=\frac{\partial}{\partial z}\left(\frac{\nu_{t}}{\sigma_{\varepsilon}} \frac{\partial \epsilon}{\partial z}\right)+c_{\varepsilon 1} \frac{\epsilon}{k} \nu_{t}\left(\frac{\partial U}{\partial z}\right)^{2} \\
& -c_{\varepsilon 2} \frac{\epsilon^{2}}{k}
\end{aligned}
$$

$\epsilon$ の輸送方程式中に現われる浮力に関する項を考慮す べきか否かについては種々の意見がある．GibsonLaunder $^{3)}$, McGuirk-Papadimitriou ${ }^{7)}$ Viollet $^{12)}$ らは, 安定成層流中の微小スケールの乱流運動が等方的である ならば，浮力効果は無視できると報告している．この仮 定は Britter et al. ${ }^{13)}$ の実験によっても支持されている. 一方, Rodi ${ }^{14)}$ は浮力生成項の係数を種々変化させた計 算を行い, 実験值との比較から浮力生成項の有効性を示 唆している.このように $\epsilon$ の輸送方程式の浮力生成項 の取扱いに関してはいまだ定説はない，検討の結果， $\epsilon$ 輸送方程式の浮力生成項は安定成層流において考慮する 必要がないこと ${ }^{15)}$ がわかったので，本論文では浮力生成 項を省略することにした。

乱流 Schmidt 数 $\sigma_{t}$ は局所的な成層安定度を表わす勾 配型 Richardson 数 $R i\left(=-(\partial B / \partial z) /(\partial U / \partial z)^{2}\right)$ の関 数として表現する Kondo et al. ${ }^{16)}$ の関係式

$$
\sigma_{t}=6.873 R i+1.0 /(1.0+6.873 R i)
$$

を採用した. モデル定数は $c_{\mu}, \sigma_{k}, \sigma_{\epsilon}, c_{\epsilon 1}$ および $c_{\epsilon 2}$ で あり，常用される值 $(0.09,1.0,1.3,1.44,1.92)$ を用 いた。

b) 代数的応力モデル (ASM)

$k^{-} \epsilon$ 二方程式モデルは $k$ および $\epsilon$ というスカラー量 から渦動粘性係数を算定することになり，乱れの非等方 性を勘案できないという久陥がある。そのためには $-\overline{u_{i} u_{j}},-\overline{u_{i} b}$ および $\overline{b^{2}}$ の輸送方程式を直接解く必要 がある. しかしながら, 方程式の数も多くなり, かつ計 算も容易ではない. しかも，大量の演算時間を必要とす 
る.

Ljuboja-Rodi ${ }^{17)}$ はレイノルズ応力モデルの基本的な 特性を保持したままで，方程式系を代数的表現に簡略化 できる代数的応力モデル（ASM）を提唱している．そ の基本的な考え方は， $\overline{u_{i} u_{j}}$-輸送方程式の非定常項，移 流項および拡散項を $k$-方程式の対応する項で近似する 方法であり，次式のように簡単化される.

$$
\begin{aligned}
& \frac{D \overline{u_{i} u_{j}}}{D t}+\operatorname{Diff}\left[\overline{u_{i} u_{j}}\right]=\frac{\overline{u_{i} u_{j}}}{k} \delta_{i j}\left(\frac{D k}{D t}-\operatorname{Diff}[k]\right) \\
& =\frac{\overline{u_{i} u_{j}}}{k} \delta_{i j}\left(P_{r}+G-\epsilon\right) \ldots \ldots \ldots \ldots \ldots \ldots \ldots \ldots \ldots \ldots \ldots \ldots \ldots \ldots \ldots \ldots \ldots \ldots \ldots
\end{aligned}
$$

ここに, $P_{r}, G$ はせん断および浮力による乱れエネル ギーの生成項， $\epsilon$ は粘性消散率である. 二次元表層密度 噴流の場合は次式で表わされる.

$$
\left.\begin{array}{l}
P_{r}=-\overline{u w} \frac{\partial U}{\partial z}=\nu_{t}\left(\frac{\partial U}{\partial z}\right)^{2} \\
G=-\overline{w b}=\frac{\nu_{t}}{\sigma_{t}}\left(\frac{\partial B}{\partial z}\right)
\end{array}\right\}
$$

この結果，レイノルズ応力方程式は次式に示されるよ うな代数的表現に簡略化できる．すべての乱流諸量を乱 れエネルギー $k$ とその粘性消散率 $\epsilon$ の 2 つの輸送方程 式を解くだけで算定できる点に ASM の利点がある.

$$
\begin{aligned}
& \overline{w^{2}}=\frac{2}{3} k\left\{c_{1}-1+\frac{P_{r}+G}{\epsilon}\left(c_{2}-2 c_{2} c_{2}^{\prime} f\right)\right. \\
& \left.+\frac{G}{\epsilon}\left(3-c_{2}-2 c_{3}+2 c_{2} c_{2}^{\prime} f\right)\right\}\left\{c_{1}+2 c_{1}^{\prime} f\right. \\
& \left.+\frac{P_{r}+G}{\epsilon}-1\right\} \\
& \overline{u^{2}}=\frac{2}{3} k\left\{\frac{P_{r}}{\epsilon}\left(3-2 c_{2}-2 c_{2} c_{2}^{\prime} f\right)+c_{1}-1\right. \\
& \left.+\frac{3}{2} c_{1}^{\prime} f \frac{\overline{w^{2}}}{k}\right\}\left\{c_{1}+\frac{P_{r}+G}{\epsilon}-1\right\}^{-1} \text {. } \\
& \overline{u w}=-c_{\mu}^{\prime} \frac{k^{2}}{\epsilon} \frac{\partial U}{\partial z}=-\frac{\overline{w^{2}}}{k}\left\{1-c_{2}+\frac{3}{2} c_{2} c_{2}^{\prime} f\right. \\
& \left.-\left(1-c_{2 b}\right) \frac{1-c_{3}}{c_{1 b}} \alpha \beta\right\}\left\{c_{1}+\frac{3}{2} c_{1}^{\prime} f\right. \\
& \left.+\frac{1-c_{3}}{c_{1 b}} \beta\right\}^{-1} \cdot \frac{k^{2}}{\epsilon} \frac{\partial U}{\partial z} \\
& \overline{u b}=-\frac{1}{c_{1 b}} \frac{k}{\epsilon} \overline{u w} \frac{\partial B}{\partial z}+\frac{c_{2 b}-1}{c_{1 b}} \overline{w^{2}} \frac{\alpha \beta}{g} \frac{\partial U}{\partial z} \\
& \overline{w b}=-\alpha \overline{w^{2}} \frac{k}{\epsilon} \frac{\partial B}{\partial z} \\
& \overline{b^{2}}=-\overline{w b} \frac{k}{\epsilon} c_{R} \frac{\partial B}{\partial z}
\end{aligned}
$$

ここに,

$$
\left\{\begin{array}{l}
\alpha=\left\{c_{1 b}+c_{1 b}^{\prime} f+2\left(1-c_{3 b}\right) c_{R} \beta\right\}^{-1} \\
\beta=-g \frac{k^{2}}{\epsilon^{2}} \frac{\partial B}{\partial z}
\end{array}\right.
$$

$c_{1}, c_{2}, c_{3}, c_{1}^{\prime}, c_{2}^{\prime}$ は圧力・ひずみ相関項のモデル定
数, $c_{1 b}, c_{2 b}, c_{3 b}, c_{1 b}^{\prime}$ は圧力・浮力変動相関項のモデル 定数であり，それらの值は $1.8 ， 0.6 ， 0.5 ， 0.5 ， 0.3$, 3. $0,0.33,0.33,0.5$ である. また, $c_{R}$ は浮力変動量 $\overline{b^{2}}$ の消散率 $\epsilon_{b}$ と $\epsilon$ の関係式 $\epsilon_{b}=\epsilon \cdot \overline{b^{2}} /\left(c_{R} k\right)$ のモデル定数 であり，0.8を採用した。これらの值はGibsonLaunder ${ }^{18)}$ の研究を参考にして決めた。なお， $c_{1}^{\prime} ， c_{2}^{\prime} お$ よび $c_{1 b}^{\prime}$ のプライムのついた定数は後述する自由水表面 の補正に関連するものである. $f$ は自由水表面の影響 を考慮した減衰関数である.

\section{（3）自由水表面の影響の評価}

椿・小松 ${ }^{19)}$ の実験によれば，二次元表層均質噴流の平 均流速分布の半值半幅 $H_{0.5}$ の流下方向への拡がり率 $d H_{0.5} / d x$ は 0.072 であった。 二次元自由噴流の拡がり 率は一般に 0.11 と報告されている. 両流動の唯一の相 違は自由水表面の有無にあるわけだから, 自由水表面の 存在が乱流特性に及ぼす影響の評価は重要である.

自由水表面の存在は鉛直方向の乱れ変動を減衰させる とともに, 乱れの長さスケールも減少させて, 鉛直方向 の運動量や浮力の乱流輸送を抑制する効果をもたらす. この意味において, 自由水表面は壁面の存在と同じよう な影響を乱流特性に及ぼすと考えられる。 GibsonLaunder ${ }^{18)}$ は Shir ${ }^{20)}$ によって提案された圧力・ひずみ 相関項における壁面修正モデルを拡張したモデルを提唱 しており,本研究では定数の值も含めてそのまま用いた. 正確な圧力・ひずみ相関項ならびに圧力・浮力変動相関 項のモデル化は Gibson-Launder ${ }^{18)}$ に記されているの で, ここでは付加条件としての減衰関数 $f$ について述 ベる.

Celik-Rodi ${ }^{21)}$ は壁面減衰関数を拡張して

$$
f=\frac{k^{3 / 2}}{c_{w} \epsilon} \cdot \frac{1}{z_{n}+0.04 k_{s}^{3 / 2} / \epsilon_{s}}
$$

を提案した.ここに, $k_{s}$ と $\epsilon_{s}$ は水表面での $k$ と $\epsilon$ の值 を示す． $z_{n}$ は自由水表面から垂直に測った距離である. 上式は, 自由水表面加の距離の増大に伴って, 補正効 果が減少することを示している. 壁面減衰関数では乱れ が局所的に平衡状態で, 速度の対数則が適用できる壁面 近傍で $f=1.0$ となるように, $c_{W}$ の值が選ばれる. そ の結果, $c_{w}$ の值は一般に 2.5 となる. 水表面減衰関数 の場合は, 自由水表面で $f$ の值が有限值となるように $0.04 k_{s}^{3 / 2} / \epsilon_{s}$ が加算される. 定数 0.04 の值は Nakagawa $e t a l .{ }^{22)}$ の開水路乱流における $\overline{w^{2}} / k$ の実測值に合 致するように決められた．また， $k_{s}^{3 / 2} / \epsilon_{s}$ は乱れ変動の 長さスケールを特徵づけるものであり, 自由水表面の存 在による長さスケールの減少を評価できる. 彼らは水表 面での粘性消散率 $\epsilon_{s}$ を次式のように特定した。

$$
\epsilon_{s}=k_{s}^{3 / 2} /(a H)
$$

ここに, $H$ は水深, $a$ は水表面上での乱れエネルギー 
$k_{s}$ の実測值に合うように定められた実験定数であり， $a$ $=0.18$ を採用した.

彼らがいみじくも指摘しているように，水表面での $\epsilon_{s}$ を特定することは粗雑な方法である. しかしながら, それは自由水表面近傍で乱れの長さスケール $l_{s} \propto k^{3 / 2} / \epsilon$ あるいは渦動粘性係数 $\nu_{t} \propto k^{2} / \epsilon$ を減少させるという望 ましい影響をもたらす利点がある．これは自由水表面の 境界条件として一般的に用いられる対称条件

$$
d \epsilon_{s} / d z=0
$$

では得られない効果である.

自由水表面近傍での乱流計測データがそしい現状では モデル化をいたずらに進めることは意味がない，本研究 では上式 (21), (22) を検討することにするが, 開水路 乱流で特定された係数值がそのまま適用できるとは考え られない, 適用に際して, 定数 $a$ の検証が必要である.

\section{3. 数値計算の概要}

\section{（1）計算方法}

離散化の考え方, ならびに計算手法は先に発表した計 算プログラム ${ }^{10)}$ に準じた. すなわち, 非定常に変動する 自由水表面の水位を直接計算する方法であり, 流れが定 常状態に漸近するまで非定常計算を行った。不要な擾乱 を抑制するために, 水位変動の空間的な連成を図る方法 を用いた. すなわち, $n+2$ 時間ステップと $n$ 時間ステッ プでの各変数を加重平均操作して, $n+2$ 時間ステップ の水位変動を implicit な差分表現に修正する方法を採 用した. 他の時間差分は leap frog 法による explicit 差 分表現とした. また, 数值分散に由来する誤差を最小に 抑えるために, 移流項の差分には二次精度の風上差分を 採用した。

計算領域は図一1に示す. 水理実験に合わせて, 塩水 を満たした長さ $400 \mathrm{~cm}$, 深さ $120 \mathrm{~cm}$ の二次元水路に淡 水を表層放流する数值実験を実施した. 表層密度噴流で は流れの変化は放出口近傍で激しく, 放出口から離れる に従って緩やかになることから, 流動の特性に応じて格 子網の間隔を変え得る不等間隔格子網を採用した. 格子 網は $\Delta x=2.0 \sim 5.0 \mathrm{~cm}$ の離散化間隔で水平 $(x)$ 方向に 88 節点, $\Delta z=0.5 \sim 2.5 \mathrm{~cm}$ で鉛直 $(z)$ 方向に 70 節点で ある. 不等格子間隔網の採用に伴う数值誤差については

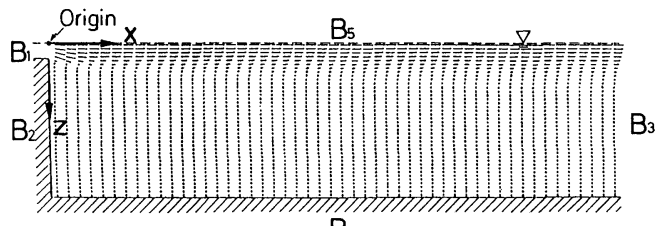

$\mathrm{B}_{4}$
すでに検討済みである ${ }^{10)}$.

放出口条件は実験值から水深 $H_{0}=2.5 \mathrm{~cm}$ で一様平均 流速分布 $U_{0}=10 \mathrm{~cm} / \mathrm{s}$, 一様平均浮力分布 $B_{0}$ とし, $B_{0}$ を $4.44,1.11,0.49,0.0 \mathrm{~cm}^{2} / \mathrm{s}$ と変えることによって， 放出口密度フルード数 $F d_{0}=U_{0} / \sqrt{B_{0} H_{0}}$ の值を 3.0 , $6.0,9.0, \infty$ と変化させた. 乱れエネルギー $k$ および 粘性消散率 $\epsilon$ は McGuirk-Papadimitriou ${ }^{7)}$ に倣い $\sqrt{k} / U_{0}=0.05$ の関係から $k_{0}=0.0025 U_{0}^{2} \mathrm{~cm}^{2} / \mathrm{s}^{2}, \epsilon_{0}=$ $k_{0}^{3 / 2} / H_{0} \mathrm{~cm}^{2} / \mathrm{s}^{3}$ の一様分布を与えた.

計算は大阪大学大型計算センターの NEC-SX-2N を 用いて行った．定常状態に達するまでの CPU 時間は $k-\epsilon$ モデルで 4.0 分, ASM で 4.9 分であった.

\section{（2）境界条件}

境界条件は図一1 の $B_{1} \sim B_{5}$ で次のように与えた。

- 放流口 $\mathrm{B}_{1}: U=U_{0}, B=B_{0}, \partial \zeta / \partial x=0, k=k_{0}$,

$$
\epsilon=\epsilon_{0} \text {. }
$$

- 壁面 $\mathrm{B}_{2}: U=0, \partial B / \partial x=0, \quad \partial k / \partial x=\partial \epsilon / \partial x=0$.

-下流端 $\mathrm{B}_{3}: \partial U / \partial x=\partial B / \partial x=0, W=\zeta=0$,

$$
\partial k / \partial x=\partial \epsilon / \partial x=0
$$

- 底面 $\mathrm{B}_{4}: W=0, \partial U / \partial z=\partial B / \partial z=0$, $\partial k / \partial z=\partial \epsilon / \partial z=0$.

- 水表面 $\mathrm{B}_{5}: \partial U / \partial z=\partial B / \partial z=0, \partial k / \partial z=0$, $\epsilon$ に関しては式 (21) あるいは式 (22) を用いる.

ここに, $\zeta(x, t)$ は自由水表面の水位変動を示す.

\section{4. 自由水表面における乱流減衰のモデル化の 検討}

\section{（1）計算条 件}

表層密度噴流の数值実験に先立って密度差のない表層 均質噴流 $\left(F d_{0}=\infty\right)$ の数值計算を行い, 自由水表面条 件および乱流モデルの整合性の検討を行った．実験的に 決めるべき定数は式 $(20)$ の $c_{w}$ と式 (21) の $a$ である. 壁面で用いられる $c_{w}=2.5$ は, 粘性消散項が生成項を 上回るエネルギー不足の水表面近傍では適当でない，予 備計算の結果, Hossain-Rodi ${ }^{23)}$ が開水路密度流の計算 で用いた $c_{W}=5.0$ を採用した. 計算条件は表一1に示す 5 ケースである. $a$ の值は彼らの用いた $a=0.18$ を参 考に 3 通り変化させて, $a$ 值の適合性を検討した。

\section{表一1 表層均質噴流の計算条件}

\begin{tabular}{c|c|c|c}
\hline Run & モデル & 水表面条件 & 拡がり率 \\
\hline H-1 & ASM & Eq. (21) with $a=1.80$ & 0.077 \\
H-2 & ASM & Eq. (21) with $a=0.90$ & 0.067 \\
H-3 & ASM & Eq. (21) with $a=0.18$ & 0.050 \\
H-4 & ASM & Eq. (22) & 0.073 \\
H-5 & $k-\epsilon$ & Eq. (22) & 0.071 \\
\hline
\end{tabular}




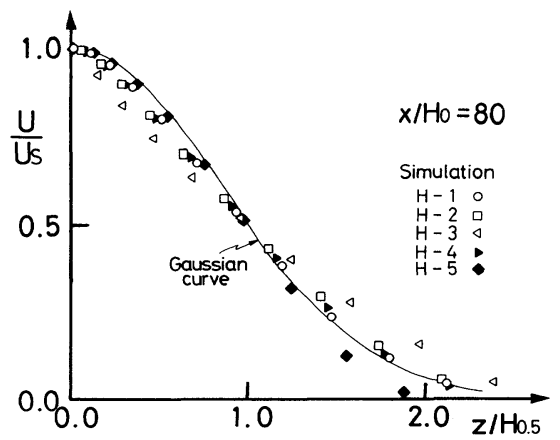

図一2 平均流速の鉛直方向分布

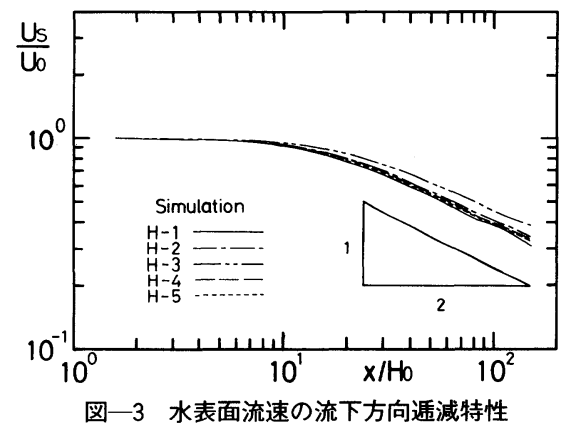

\section{(2) 計算結 果}

図一2 は $x / H_{0}=80$ の流れの確立領域での平均流速 $U$ の鉛直方向分布を示す．慣例に従って，縦軸と横軸は水 表面速度 $U_{s}$ と流速分布の半値半幅 $H_{0.5}$ で無次元表示し た. 表層噴流の確立領域においても，自己相似性が平面 噴流と同様に成り立つことが知られている．すなわち， 平均流速分布は一般に Gauss 分布で近似できる，計算 結果は $a=0.18$ を用いた Run H-3 を除いてこの特性を 示している．また，図一3に示す水表面流速 $U_{s}$ の旡減 特性も放流口からの距離 $x$ の $-1 / 2$ 乗則に従って減少 しており，Run H-3 を除いて自己相似性が成立してい ることが確認できる.

半值半幅の拡がり率 $d H_{0.5} / d x$ の計算值を表一 1 の最 終欄に示す. 自由水表面で $d \epsilon_{s} / d z=0$ の対称条件を用 いた $k^{-} \epsilon$ モデルおよび ASM の計算值が椿・小松 ${ }^{199} の$ 実験値 0.072 と合致することがわかる. 一方, 式 (20) と式 (21) の減衰関数 $f$ を用いて水表面補正した計算 では， $a$ の值を小さく見積もれば，拡がり率が減少する 傾向を示す．換言すれば，自由水表面の存在による乱れ 変動の長さスケールの減少を過大に評価すれば，それは 平均流速分布を水表面近傍で溲せさせる効果を及ぼし, 結果として噴流の拡がりを減少させることになる． $a=$ 1.8 に選んだ Run H-1 では対称条件の計算結果 (Run $\mathrm{H}-4)$ より過大な拡がりを示しており, 減衰関数 $f$ を 導入する目的である乱れの減衰効果がうまく表現されて

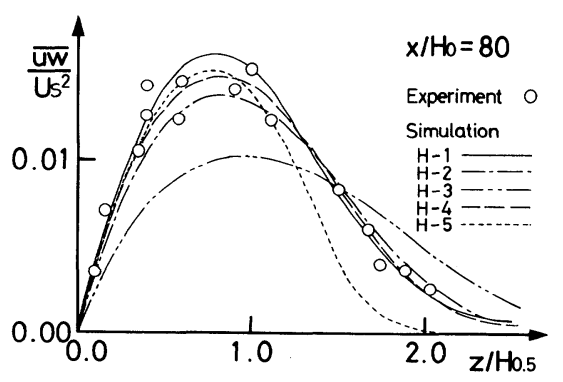

図一4 レイノルズ応カの鉛直方向分布

いない.

図一4 はレイノルズ応力 $\overline{u w} / U_{s}^{2}$ の鉛直方向分布を示 す. 図中の丸印は椿・小松 $\left.{ }^{19}\right)$ の $x / H_{0}=125$ での実験値 である. $a=0.18$ の計算（Run H-3） は最も小さい長さ スケールを仮定した場合に相当するが， $\overline{u w} / U_{s}^{2}$ の最大 值は実験值の $2 / 3$ 程度まで落ちている，長さスケールを 小さく仮定し過ぎた結果，水表面での乱流減衰効果があ まり有効に働かないために，鉛直下方への運動量の輸送 が促進されている.一方, $k-\epsilon$ モデルの計算 (Run H-5) では $z / H_{0.5}>1.0$ の範囲で $\overline{u w} / U_{s}^{2}$ の過剩な減少が認め られる. 式 (8)の $c_{\mu}$ の值は $k-\epsilon$ モデルでは噴流断面 全域で一定值 0.09 であるのに対して，ASM では水表 面近傍では小さく, 水深とともに増加して $z / H_{0.5}>1.0$ の範囲で約 0.1 の值となる (式 (16) 参照). この $c_{\mu}$ の違いが $k-\epsilon$ モデルで計算した $\overline{u w} / U_{s}^{2}$ の減少をもた らしたものと考えられる. 他の 3 ケースは実験值を良好 に予測しており，優劣つけ難い。しかし，水理諸量の流 下方向変化を調べた場合， $\epsilon_{s}$ を表層厚さ $H$ 之関係付け る Run H-2 では $\overline{u w} / U_{s}^{2}$ の分布は流下方向に相似形を 保持する. これに対して, 対称条件 $d \epsilon_{s} / d x=0$ を用い たRun H-4では，その值はわずかではあるが，一様に 増加する傾向にある．たとえば, $\overline{u w /} U_{s}^{2}$ の最大值およ びその水深 $z / H_{0.5}$ の值を比較すると, $x / H_{0}=80$ では 0.0146 と $0.79, x / H_{0}=120$ では 0.0152 と 0.81 であっ た.すなわち, 噴流特有の自己相似性からみれば, 式 (21) を用いた水表面補正が適切であるといえる.

上述の検証を総合的に判断して, 以下では $a$ の值と して 1.0 を用いて表層密度噴流の計算を行う。つまり， 本モデルでは水表面近傍の乱れ変動の長さスケール $l_{s}$ を表層噴流厚 $H$ を用いて $l_{s}=0.04 \cdot H$ で与えることに なる.この点に関しては精度良い水理実験をまって, 詳 細に検討し直す必要があるのはもちろんのことである.

\section{5. 表層密度噴流の数值計算}

\section{（1） $\boldsymbol{k}-\epsilon$ 二方程式モデルの適用限界}

図一5 は $k^{-} \epsilon$ 二方程式モデルを用いて計算した流下方 


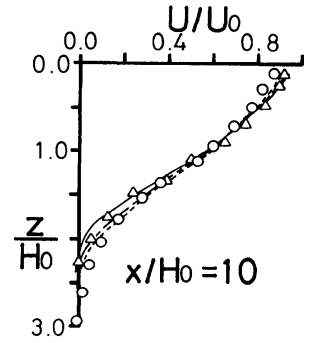

Simulation

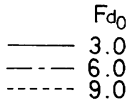

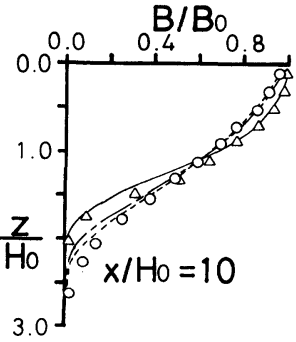

Experiment

$F_{d_{0}}$

$\triangle 3.3$
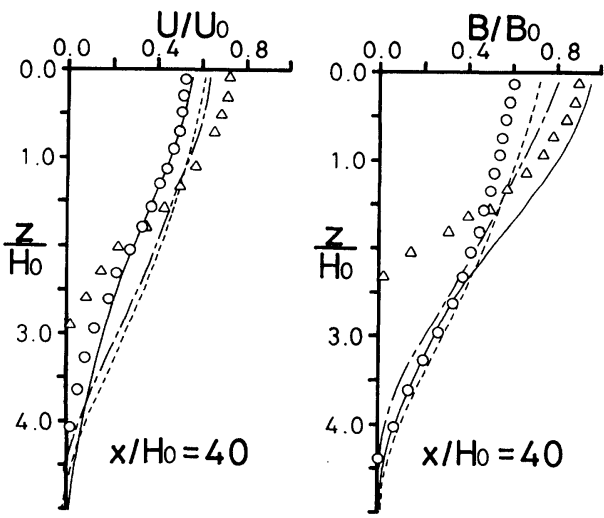

図一5 $k-\epsilon$ モデルによる平均流速と平均浮力の鉛直分布

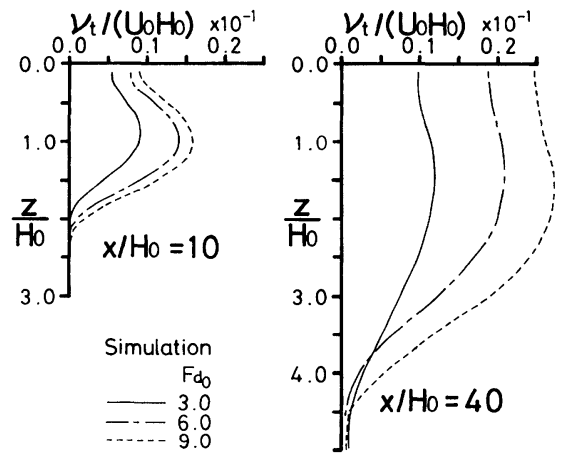

図一 $6 k-\epsilon$ モデルによる渦動粘性係数の鉛直分布

向平均流速 $U$ と平均浮力 $B$ の計算值と中辻 ${ }^{11}$ による実 験値を比較したものである．初期運動量流束の影響の強 い流下位置 $x / H_{0}=10$ では, 計算值と実験値とは良好に 一致している. しかし, 成層効果が優勢になる $x / H_{0}=$ 40 になると，両者の一致度は悪い，特に，その傾向は 平均浮力の分布に顕著である.

図一6は図一 5 に対応する流下位置での渦動粘性係数 $\nu_{t}$ の鉛直分布を示す．慣性力が増すにつれて，すなわち $F d_{0}$ の值の増大とともに， $\nu_{t}$ の絶対值が増加する傾向 はうまく表現されている. しかし，その絶対值は表層噴 流の断面全域でおしなべて大きい. 特に, $x / H_{0}=40$ の 計算で $\nu_{t} / U_{0} H_{0}$ の值が 0.005 以下になる水深が $F d_{0}$ の 值に無関係に $z / H_{0}=4.0$ であるのは, 理解し難い計算 結果である. 渦動粘性係数の值が大きいことは運動量の 鉛直方向輸送が大きいことを意味しており，結果として 平均流速分布の下方への過大な拡がりをもたらしてい る. $k^{-} \epsilon$ モデルでは渦動粘性係数の算出において方向性 が全く考慮されないことに原因して，このような結果に なったと考えられる.

しかしながら, 渦動粘性係数の評価に, $\mathrm{Webb}^{24)}$ の経 験公式を用いた室田・中辻 ${ }^{10}$ の計算結果と比較すれば, $k-\epsilon$ モデルによる計算值は $x / H_{0}=10$ での実験值の傾向 を良好に説明している．このことから， $k^{-} \epsilon$ 二方程式モ デルはせん断効果の卓越した乱流場に対しては合理的な 数値計算法であると結論付けられる.

（2）代数的レイノルズ応カモデル（ASM）の適用

a）平均流速分布之平均浮力分布

図一7,8 は ASM を用いて計算した平均流速 $U$ と平 均浮力 $B$ の鉛直分布の流下方向変化を示す. $U / U_{0}$ お よび $B / B_{0}$ の流下方向変化は $k^{-} \epsilon$ モデルの計算結果 (図 一5）と比較して格段に改善され, 実験值と良好に一致 している，特に，密度境界面の計算值と実験值との一致 度は非常に良い，ASM では浮力による成層効果が計算 結果にうまく考慮され, 平均流速と平均浮力分布の鉛直 下方への拡がりが抑制されていることが明瞭である.し かし, 水表面近傍の $U$ と $B$ の逓減割合に関しては計算 值の方が実験值と比べて少し小さい傾向にある.

図一9 は, 後ほど示す $\overline{u w}$ および $\overline{w b}$ の計算值から求 めた渦動粘性係数 $\nu_{t}$ 之乱流 Schmidt 数 $\sigma_{t}$ の鉛直分布を 示す. 図一 6 との比較のために, $x / H_{0}=40$ での計算値 を示した. $k^{-} \epsilon$ モデルの $\nu_{t} / U_{0} H_{0}$ の值と比較して, ASM の計算值は全般的に小さい，しかも，放流口密度 フルード数 $F d_{0}$ の減少とともに, $\nu_{t}$ の值が 0 に漸近す る水深が小さくなっているのが, 特徽的に現われている. この結果, 鉛直下方への運動量輸送が抑えられ, 平均流 速分布が実験で得られた分布形と良く一致するように なったと考えられる.つまり，レイノルズ応力の算出に 際して, 浮力勾配項を導入して成層効果を考慮した影響 （式（16））が渦動粘性係数の鉛直分布に明瞭に現われ ている.

他方, 平均流速と平均浮力の計算值と実験值との一致 度が水表面近傍であまり良くないのは, $\nu_{t} / U_{0} H_{0}$ の值が 水表面近傍で少し小さいことに原因している．このこと は式 (12) で水表面での粘性消散率 $\epsilon_{s}$ を少し過大に評 

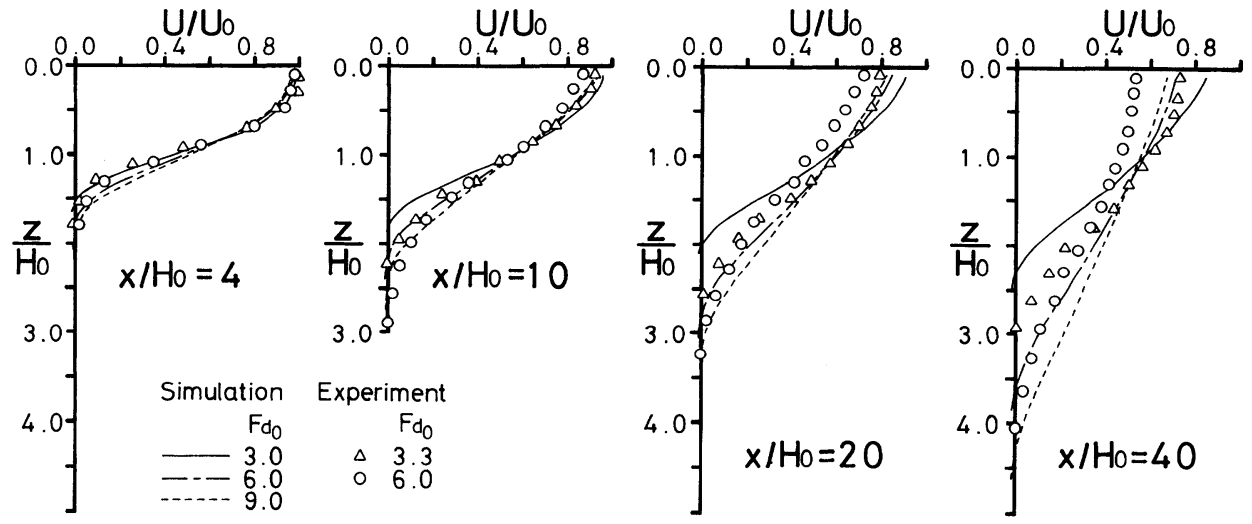

図一7 ASM による平均流速 $U / U_{0}$ の鉛直分布の流下方向変化
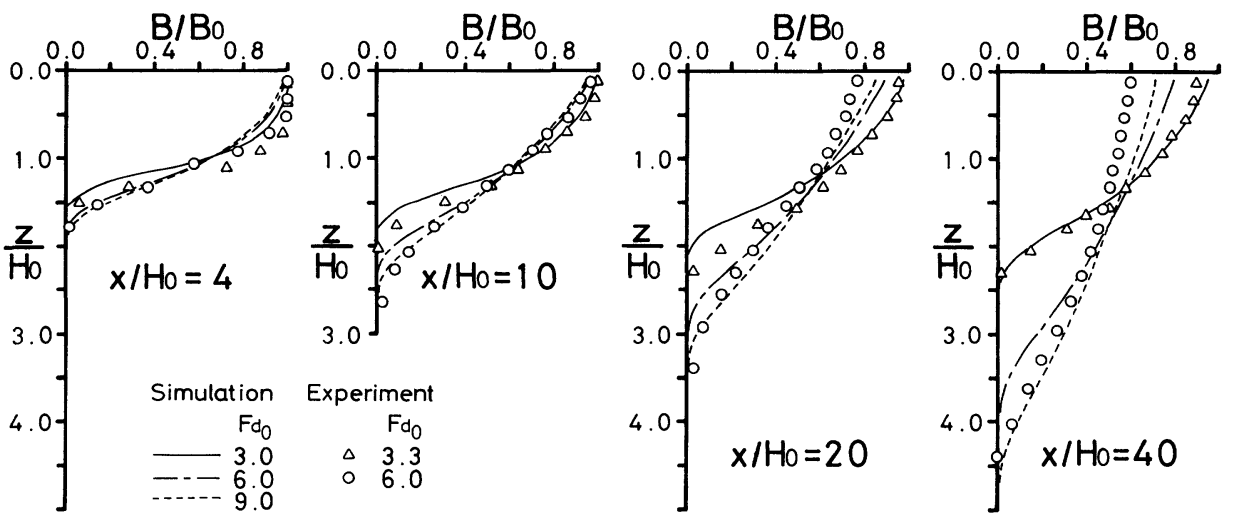

図一8 ASM による平均浮力 $B / B_{0}$ の鉛直分布の流下方向変化

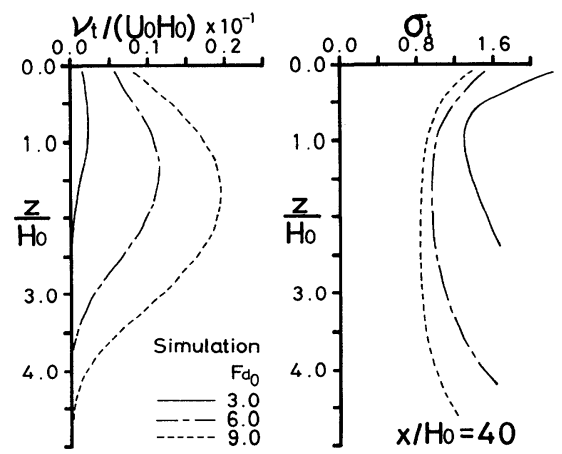

図一9 渦動粘性係数と乱流 Schmidt 数の鉛直分布

価したことと関連している．換言すれば，水表面での乱 流変動の長さスケール $l_{s}$ を小さく見積り過ぎたことに なる. 4. で考察したように, $l_{s}$ は $l_{s}=0.04 \mathrm{H}$ の関係を 通して表層噴流厚 $H$ と関係付けられる。 つまり，本モ デルにおいては成層効果による $H$ の減少が水表面近傍 の乱れスケールの減少を直接的にもたらす結果となる. 水表面の存在による乱流の減少が成層化現象とざのよう
に関連しているのかについては, 現象の理解も含めて, 今後詳細に検討する必要がある.

渦動粘性係数亡渦拡散係数の比で表わされる乱流シュ ミット数 $\sigma_{t}\left(=\nu_{t} / \Gamma_{t}\right)$ の值は, $F d_{0}$ 数の小さいほど, また水深の増加とともに，増加する傾向にある．成層効 果の影響が $\sigma_{t}$ の值の増大に明瞭に現われており,これ は既往の実験および実測で得られた結果と一致してい る。また， $\sigma_{t}$ は水表面近傍ならびに密度境界面近傍で 最大值となる特異な分布を示している．この結果は両境 界面近傍で運動量の乱流輸送が物質の乱流拡散を上回る ことを示唆しており，次節で述べる乱流の非等方性と関 連して興味深い。

b）乱流諸量の鉛直分布

図一10 は乱れ強度 $u^{\prime}, w^{\prime}, b^{\prime}$ および鉛直方向乱流浮 力流束 $\overline{w b}$ の $x / H_{0}=40$ での鉛直分布を示す．また，図 -11 はレイノルズ応力 $\overline{u w}$ の鉛直分布の流下方向変化 を示す. 図からわかるように, 乱れ強度 $u^{\prime}, w^{\prime}$ および $b^{\prime}$ に関して計算值と実験値とは非常に良く一致してお り，注目に値する．計算された非等方性度 $\overline{w^{2}} / \overline{u^{2}}$ は $w^{\prime}$ 

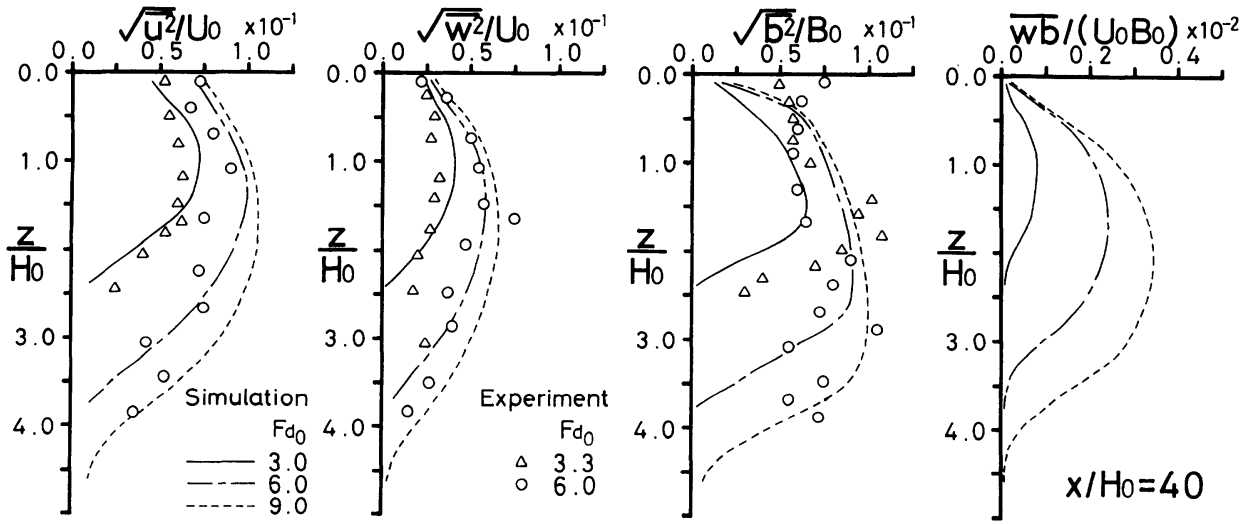

図一10 ASM による乱流諸量の鉛直分布 $\left(x / H_{0}=40\right)$

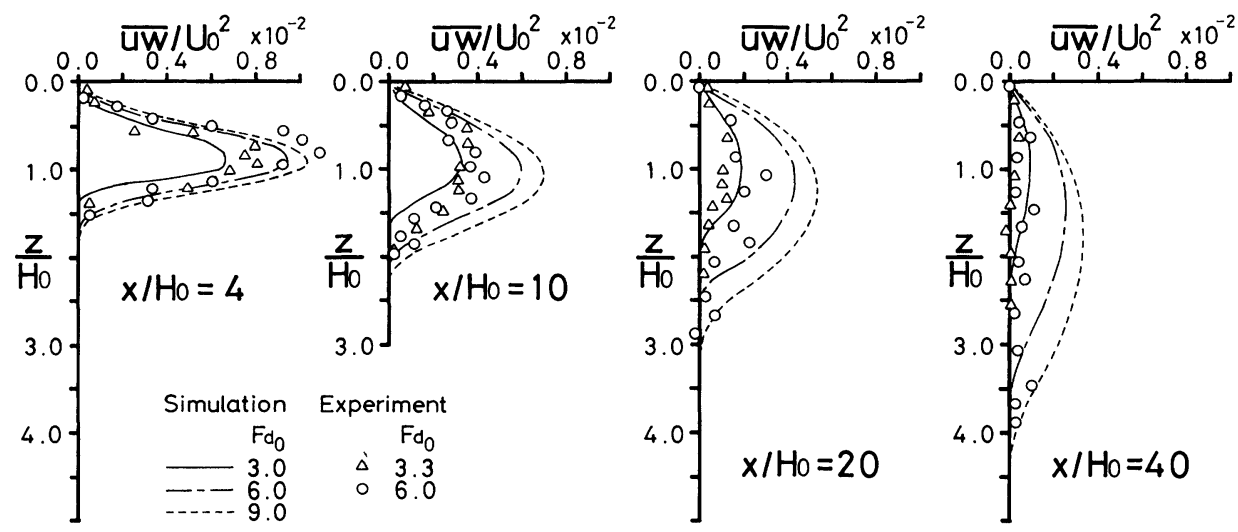

図一11 ASM によるレイノルズ応力 $\overline{u w} / U_{s}^{2}$ の鉛直分布の流下方向変化

の最大值を示す水深で 0.329 ～ 0.388 の範囲であるのが, 水表面近傍では 0.165 之減少する. 自由水表面の存在に より鉛直方向の乱流変動が㧕制される実験事実が本モデ ルの計算で良好に再現されていることがわかる。一方， レイノルズ応力 $\overline{u w}$ の計算值は $x / H_{0}=4$ を除いて実測 值より全般的に少し大きい值となる. $\overline{w b}$ の実験值はあ まりにも小さく，比較が困難であるため，図一10では 割愛した. $u^{\prime}, w^{\prime}$ および $b^{\prime}$ の計算値と実験值とが良好 に一致するのに対して，その相乗積である $\overline{u w}$ 計算值が実験值とあまり合っていないのは不可思議であ る.しかし, $\overline{u w}$ および $\overline{w b}$ の鉛直分布の定性的傾向は 両者でよく一致している．実験值の信頼性を再検討する 必要があるかもしれない.

c）乱流諸量之成層度との関連性

成層せん断流の局所的な安定度を示す指標として勾配 型リチャードソン数 $R i$ が良く用いられる. そこで, 流 速変動の非等方性度 $\overline{w^{2}} / \overline{u^{2}}$ および相関係数 $\overline{u w} / u^{\prime} w^{\prime}$ 之 $R i$ の関係を示したのが図一12,13である.上図は計算 值，下図は実験値を示す。計算值は実験値と同様に相当
の散乱状態にあるが，平均した最適曲線の絶対値ならび にその $R i$ との関係は両者でよく合致している.すなわ ち, Ri が大きくなると, つまり成層安定性が強まると, $\overline{w^{2}} / \overline{u^{2}}$ の値は小さくなり，鉛直方向の乱流変動が抑制さ れていることがわかる. また，レイノルズ応力の相関係 数 $\overline{u w} / u^{\prime} w^{\prime}$ も $R i$ の増加とともに減少する傾向を示す. これは，成層安定化に伴って $u$ と $w$ の相関がなくなり， 鉛直方向への運動量の乱流輸送が抑えられていることを 意味する。

図中の実線は，小森ら ${ }^{25}$ が開水路内の安定成層流で得 た実験值の最適曲線である，彼らの実験值は著者らの計 算值ならびに実験值とおおむね一致するが， $R i$ 数が 0.1 以上の強安定成層流中で $\overline{w^{2}} / \overline{u^{2}}$ の值が増加する特異 な結果を示している．彼らの解説によれば，その領域で は波状運動が支配的であり，平均流速勾配や平均温度勾 配に逆らった乱流輸送が生じている，一般的には，著者 らの計算值ならびに実験值の示す傾向が成層せん断流の 物理現象として妥当であろう.

次に, 渦拡散係数と渦動粘性係数の比 $\Gamma_{t} / \nu_{t}\left(=1 / \sigma_{t}\right)$ 

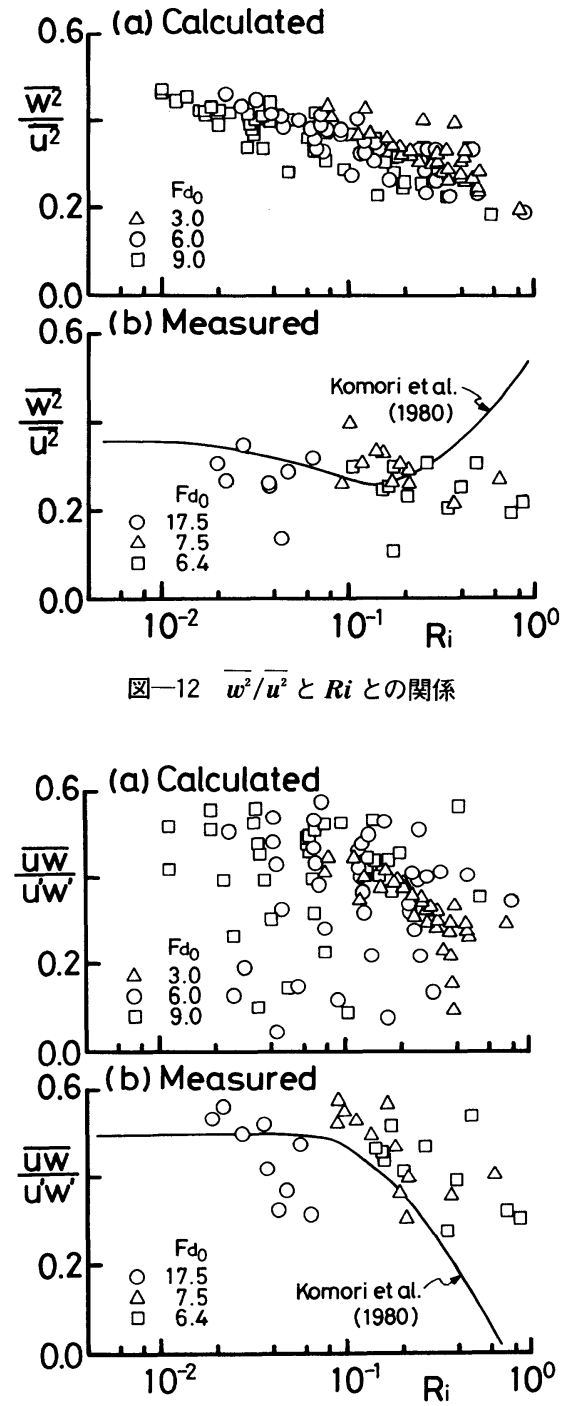

図一13 $\overline{u w} / \boldsymbol{u}^{\prime} \boldsymbol{w}^{\prime}$ と $\mathrm{Ri}$ との関係

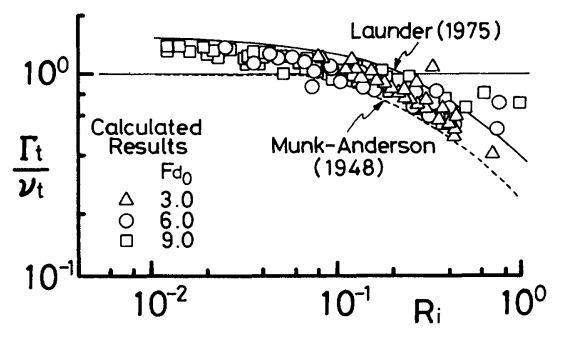

図一14 $\Gamma_{t} / \nu_{t}$ と $R i$ との関係

と $R i$ 数との関係を図一 14 に示す. $\Gamma_{t} / \nu_{t}$ の計算值は安 定度の増加とともに減少する傾向にあり, その上限と下 限は図中に実線と破線で示す Launder ${ }^{26)}$ と MunkAnderson $^{27)}$ の理論結果とよく一致する. 結果として,
物質の乱流拡散が運動量の乱流輸送に比べて浮力の影響 をより大きく受けることが明らかである．以上の比較か ら, 本モデルが乱流輸送の $R i$ 数依存性をおおむね良好 に再現できることがわかる。

\section{6. 結 論}

代表的な乱流二方程式モデルである $k-\epsilon$ モデルと代 数的レイノルズ応力モデル (ASM) を用いて二次元表 層密度噴流の数值計算を行い, 実験結果との比較から乱 流モデルの基礎的な検討を行った.

$k-\epsilon$ モデルは乱流変動の非等方性を適切に表現し得な いために，鉛直方向の乱流輸送を過大に評価することが わかった。一方, ASM は Gibson-Launder ${ }^{17)}$ に倣い圧 力・ひずみ相関項ならびに圧力・浮力変動項に対して水 表面補正を行った結果, 表層密度噴流の流動特性と乱流 特性を良好に予測することが確認された.ASM の計算 值と実験值との一致度は満足すべきものであった。

また, 乱流諸量と成層度との関連を調べたところ, 乱 流輸送のリチャードソン数への依存性が数值結果に良好 に再現されていることが認められた.

最後に, 本研究は昭和 62-63 年度文部省科学研究費 ・ 一般研究 C (代表者・中过啓二, 課題番号 62550375) の 補助を受けたことを記し，謝意を表する.

1）室田 明・中辻啓二・中村圭二郎：二次元表層密度流の 形態分類, 土木学会論文集, 第 363 号 $/$ II -4, pp. 107 113, 1985.

2) Patanker, S. V. and Spalding, D. B. : A Calculation Procedure for Heat, Mass and Momentum Transfer in Three-dimensional Parabolic Flows, Intl. J. Heat Mass Transfer, Vol. 15, pp. 1787 1806, 1972.

3) Gibson, M. M. and Launder, B.E. : On the Calculation of Horizontal, Turbulent, Free Shear Flows Under Gravitational Influence, J. Heat Transfer, Trans. ASME, C 98, pp. 81 87, 1976.

4) McGuirk, J. J. and Rodi, W. : Mathematical Modelling of Three-dimensional Heated Surface Jets, J. Fluid Mech., Vol. 95, pp. 604 634, 1979.

5) Raithby, G.D. and Schneider, G.E. : The Prediction of Surface Discharge Jets by a Three-dimensional Finite Difference Model, J. Heat Transfer, Trans. ASME, Vol.102, pp. 138 145, 1980.

6) Leschziner, M. A. : Numerical Prediction of the Internal Density Jump, Proc. 18th IAHR Congress, Cagliari, Itary, Ba 4, pp. 25 31, 1979.

7) McGuirk, J. J. and Papadimitriou, C. : A Numerical Study of the Internal Hydraulic Jump, Intl. Sympo. on Buoyant Flows, Athens, Greece, pp. 242 255, 1986.

8）松梨順三郎・岡田俊文・黒林寛治：乱流モデルによる表 層密度噴流の解析, 第 31 回水理講演会論文集, pp. 503 
５08, 1987.

9）岩佐義朗・細田 尚・伊藤邦展：乱流モデルによる Buoyant Surface Jet の数值解析, 京都大学防災研究所年 報, 第 30 号, B-2, 583 595, 1987.

10）室田 明・ 中辻啓二：二次元表層密度流の数值解析, 第 30 回水理講演会論文集, pp. 715 720，1986.

11）中辻啓二：表層密度噴流の混合機構と拡がりに関する基 礎的研究, 大阪大学学位論文, 104 pp., 1984.

12) Viollet, P. L. : Turbulent Mixing in a Two-layer Stratified Shear Flow, Proc. 2nd Intl. Sympo. on Stratified Flows, Trondheim, Norway, pp. 315 325, 1980.

13) Britter, R.E., Hunt, J.C.R., Marsh, G. L. and Snyder, W. H. : The Effect of Stable Stratification on Turbulent Diffusion and the Decay of Grid Turbulence, J. Fluid Mech., Vol.127, pp. 27 44, 1983.

14) Rodi, W. : Influence of Buoyancy and Rotation on Equations for the Turbulent Length Scale, 2nd Sympo. on Turbulent Shear Flows, London, England, pp. 10-37 $\sim 42,1979$.

15）室田 明・中辻啓二・藤崎 豊：乱流モデルの成層せん 断流への適用, 土木学会第 33 回水理講演会論文集, pp. 583 588, 1989.

16) Kondo, J., Kanechika, O. and Yasuda, N. : Heat and Momentum Transfer under Strong Stability in the Atmospheric Surface Layer, J. Atm. Sci., Vol. 35, pp. 1012 1021, 1978.

17) Ljuboja, M. and Rodi, W. : Calculation of Turbulent Wall Jet with an Algebraic Reynolds Stress Model, J. Fluid Engng., Vol. 102, pp. 350 356, 1980.

18) Gibson, M. M. and Launder, B. E. : Ground Effects on Pressure Fluctuations in the Atmospheric Boundary
Layers, J. Fluid Mech., Vol. 86, pp.491 511, 1978.

19）椿東一郎・小松利光: 2 次元表面密度噴流における流れ の特性と連行現象, 土木学会論文報告集, 第 273 号, pp. $69 \sim 81,1978$.

20) Shir, C. C. : A Preliminary Numerical Study of Atomospheric Turbulent Flows in the Idealized Planetary Boundary Layer, J. Atm. Sci., Vol. 30, pp.1327 1339, 1973.

21) Celik, I. and Rodi, W. : Simulation of Free-Surface Effects in Turbulent Channel Flows, Physico-Chem. Hydrodyn., Vol. 5, pp. 217 227, 1984.

22) Nakagawa, H., Nezu, I. and Ueda, H. : Turbulence of Open Channel Flow over Smooth and Rough Beds, Proc. JSCE, Vol.241, pp. 155 168, 1975.

23) Hossain, M. S. and Rodi, W. : Mathematical Modelling of Vertical Mixing in Stratified Channel Flow, Proc. 2nd Intl. Sympo. on Stratified Flows, Trondheim, Norway, pp. 280 291, 1980.

24) Webb, E. K. : Profile Relationships: the Log-linear Range and Extension to Strong Stability, Quart. J. R. Met. Soc., Vol.96, pp. 67 90, 1970.

25）小森 悟 - 植田洋匡 - 荻野文丸 · 水科篤郎：熱的に成層 化された流れの中の乱流拡散係数に及ぼす浮力効果, 国 立公害研究所研究報告, 第 17 号, pp. 73 88, 1980.

26) Launder, B. E. : On the Effects of a Gravitational Field on the Turbulent Transport of Heat and Momentum, J. Fluid Mech., Vol.67, pp. 569 581, 1975.

27) Munk, W.H. and Anderson, E. R. : Notes on a Theory of the Thermocline, J. Marine Res., Vol.7, pp.276 295, 1948.

(1988.11.16 • 受付) 